\title{
Depression and Quality of Life in Patients with Neurological Disorder in a Malaysian Hospital
}

\author{
Priscilla Das, Nyi Nyi Naing, Nadiah Wan-Arfah, KO Naing Noor Jan, Yee Cheng Kueh, \\ Kantha Rasalingam
}

\begin{abstract}
Objective: To investigate association between major depressive disorder (MDD) and quality of life in patients with neurological disorder.

Methods: This cross-sectional study was carried out at a Malaysian hospital between April 2016 and December 2016 using convenience sampling. Patients aged $\geq 18$ years with intracranial tumour or other brain disorders were invited to participate. Quality of life was assessed using the European Organisation for Research and Treatment of Cancer Quality of Life questionnaire version 3.0; diagnosis of MDD was made using Mini International Neuropsychiatric Interview.

Results: Of 122 patients approached, 100 (66 women and 34 men) were included (response rate, 93.5\%), with a mean age of 45.3 years. The prevalence of MDD in patients with neurological disorder was $30 \%$. Compared with non-depressed patients, patients with MDD had poorer global health status / quality of life $(p=0.003)$, and reduced physical $(p=0.003)$, role $(p=0.021)$, emotional $(p<0.001)$, cognitive $(\mathrm{p}=0.004)$, and social $(\mathrm{p}=0.007)$ functioning, as well as more symptoms of fatigue $(\mathrm{p}=0.004)$, pain $(\mathrm{p}<0.001)$, dyspnoea $(\mathrm{p}=0.033)$, insomnia $(\mathrm{p}<0.001)$, appetite loss $(\mathrm{p}=0.002)$, constipation $(\mathrm{p}=0.034)$, diarrhoea $(\mathrm{p}=0.021)$, and financial difficulties $(\mathrm{p}=0.039)$.

Conclusion: Patients with MDD had reduced quality of life. Fatigue, pain, dyspnoea, insomnia, appetite loss, constipation, diarrhoea, and financial difficulties were prevalent among patients with MDD.
\end{abstract}

Key words: Brain diseases; Brain neoplasms; Depressive disorder, major; Quality of life

Priscilla Das, Bsc (Biology), MSc(Community Health), PhD(Community Medicine), Unit of Biostatistics \& Research Methodology, School of Medical Sciences, Universiti Sains Malaysia, Kubang Kerian, Kelantan, Malaysia; Faculty of Health Sciences, Asia Metropolitan University, Selangor Darul Ehsan, Malaysia

Nyi Nyi Naing, MBBS, MPH, DTM \& H, MSc (CTM), MMedStats, Institute for Community (Health) Development, Universiti Sultan Zainal Abidin, Kuala Nerus, Terengganu, Malaysia

Nadiah Wan-Arfah, BSc (Nursing), MSc (Medical Statistics), PhD (Statistics), Institute for Community (Health) Development, Universiti Sultan Zainal Abidin, Kuala Nerus, Terengganu, Malaysia

KO Naing Noor Jan, MBBS (Rgn), MMed (Psy)(USM), Department of Psychiatry, Faculty of Medicine and Health Sciences, Universiti Putra Malaysia, Serdang, Selangor, Malaysia

Yee Cheng Kueh, PhD (Biostatistics), MSc (Medical Statistics), BSc (Applied Science Mathematics), Unit of Biostatistics \& Research Methodology, Department of Psychiatry, School of Medical Sciences, Universiti Sains Malaysia, Kubang Kerian, Kelantan, Malaysia

Kantha Rasalingam, MBBS, MMed (Neurosurgery), Department of Neuroscience, Hospital Kuala Lumpur, Kuala Lumpur, Malaysia

Address for correspondence: Dr Priscilla Das, Unit of Biostatistics \& Research Methodology, School of Medical Sciences, Universiti Sains Malaysia, 16150 Kubang Kerian, Kelantan, Malaysia.Email:daspriscilla@yahoo.com

Submitted: 27 December 2017; Accepted: 24 April 2018

\section{Introduction}

Astrocytic glioma, medulloblastoma, and meningothelial tumours are common nervous system tumours. ${ }^{1}$ Neoplastic progression or its treatment may cause major depressive disorder (MDD) symptoms, including anorexia, fatigue, reduced concentration, and insomnia secondary to pain. ${ }^{2}$ In a mouse model, chronic behavioural stress results in greater tumour burden and more invasive growth of ovarian carcinoma cells. ${ }^{3}$ Glial cells support the network of brain systems. Compared with people without depression, people with depression have noticeable changes in glial cells, including reduced frontal cortical glial cell density and neuronal size. ${ }^{4-6}$

The diagnosis of brain tumour has a severe negative influence on patient quality of life, including emotional, cognitive, and physical functioning. ${ }^{7}$ Untreated depression affects the hospital stay, therapy compliance, ability to selfcare, quality of life, and survival rate of patients with brain tumour. ${ }^{7}$ Studies of psychiatric disorders and quality of life in patients with cancer in Western countries have been reported. ${ }^{8-10}$ However, to the best of our knowledge, there are no such studies in Malaysia. The quality of life may be a fundamental mechanism that explains depression in patients with intracranial tumour or other brain disorder. Therefore, the present study aimed to investigate association between MDD and quality of life in patients with neurological disease.

\section{Methods}

The present study was approved by the Medical Research $\&$ Ethics Committee of the Ministry of Health of Malaysia 
(NMRR-16-1134-29874 (IIR) and Human Research Ethics Committee of Universiti Sains Malaysia (USM/ JEPeM/16050178).

This cross-sectional study was conducted in the neurological unit at Hospital Kuala Lumpur Malaysia between April 2016 and December 2016 using convenience sampling. The hospital is a tertiary referral centre for neurological diseases (including intracranial tumour and other brain disorders).

Sample size was calculated using a single proportion formula: ${ }^{11}$

$$
\mathrm{n}=\mathrm{Z}^{2} \mathrm{P}(1-\mathrm{P}) / \mathrm{d}^{2}
$$

where $\mathrm{Z}$ is the level of confidence (1.96 standard errors from the mean, with a level of significance of $\alpha=0.05$ ), $P$ is the expected prevalence of MDD among all brain disorders (assumed to be $6.5 \%{ }^{12}$ ), and $\mathrm{d}$ is the precision of $\mathrm{P}$ (set at $5 \%$ ). Considering a dropout rate of $15 \%$, a sample size of 107 brain disorder patients were required.

Patients aged $\geq 18$ years with neurological disorder who were able to read Malay, English, Mandarin, or Tamil and were conscious and responsive were invited to participate. Medical records were retrieved, and sociodemographic and medical data collected. Quality of life was assessed using the European Organisation for Research and Treatment of Cancer Quality of Life questionnaire version 3.0 (EORTC QLQ-C30); the diagnosis of MDD was made using the Mini International Neuropsychiatric Interview. ${ }^{13-15}$ For EORTC QLQ-C30, scores for all scales range from 1 (not at all) to 4 (very much), except for the global health status scale that ranges from 1 (very poor) to 7 (excellent). The raw score for each scale was linearly transformed to scores $0-100$. Higher scores in the functioning scale indicate better global health status, whereas higher scores in the symptom scale indicate more symptoms. ${ }^{16}$

Data were analysed using SPSS (Windows version 22.0; IBM Corp, Armonk [NY], US). The Mann-Whitney $U$ test was used for comparison of non-parametric data between patients with MDD and non-depressed patients. A $p$ value of $<0.05$ was considered statistically significant.

\section{Results}

Of 122 patients approached, 22 were excluded owing to age $<18$ years $(\mathrm{n}=10)$, other diagnosis $(\mathrm{n}=3)$, and withdrawal or incomplete study $(\mathrm{n}=9)$ and 100 (66 women and 34 men) were included (response rate, $93.5 \%$ ), with a mean age of 45.3 years. Of the 100 patients, most were in the agegroup of 41-50 years (25\%), followed by $31-40$ years $(21 \%)$ and 51-60 years $(21 \%)$ [Table 1].

The prevalence of MDD in patients with neurological disorder was $30 \%$. Compared with non-depressed patients, patients with MDD had poorer global health status / quality of life $(\mathrm{p}=0.003)$, and reduced physical $(\mathrm{p}=0.003)$, role $(\mathrm{p}$ $=0.021)$, emotional $(\mathrm{p}<0.001)$, cognitive $(\mathrm{p}=0.004)$, and social ( $\mathrm{p}=0.007)$ functioning, as well as more symptoms of fatigue $(\mathrm{p}=0.004)$, pain $(\mathrm{p}<0.001)$, dyspnoea $(\mathrm{p}=0.033)$, insomnia $(p<0.001)$, appetite loss $(p=0.002)$, constipation $(\mathrm{p}=0.034)$, diarrhoea $(\mathrm{p}=0.021)$, and financial difficulties $(\mathrm{p}=0.039)$ [Table 2].

\section{Discussion}

In the present study, the prevalence of MDD among patients with neurological disorder was $30 \%$, which is comparable with the $28 \%$ of patients with brain tumour who have MDD. ${ }^{17}$ Depression was prevalent among patients with brain tumour around the time of diagnosis or treatment. ${ }^{18}$ The prevalence of depression among primary brain tumour patients has been reported to be $2.5 \%$ to $15.4 \%,{ }^{12}$ and as much as $44 \%$ among all brain tumour patients. ${ }^{19} \mathrm{~A}$ study in Taiwan found that the prevalence of depression among patients with cancer was $20 \% .{ }^{20}$ Asian populations typically have lower prevalence of MDD than do Western populations..$^{21} \mathrm{~A}$ systematic review of 100 studies found that the prevalence of depression among patients with cancer ranged from $0 \%$ to $58 \%$, independent of site and stage of the cancer. ${ }^{22}$

In the present study, patients with MDD had significantly reduced physical, role, emotional, cognitive, and social functioning than non-depressed patients. Symptoms of MDD such as worrying about the future, disappointed feelings, tiredness, reduced memory power, difficulties in sleeping, and decreased physical functioning have been reported to lead to tremendous losses from noxious stimuli and the environment. ${ }^{23}$ Such patients have been reported to have serious emotional and physical limitations and poor mental health status..$^{24,25}$ Predictors of MDD include frontal region of tumour location, combined symptoms of sadness and lack of motivation, and family psychiatric history. ${ }^{26}$ The effect of depression on the immune system may influence resistance to tumour progression in patients with cancer. ${ }^{27}$

The current study also reported more symptoms of fatigue, pain, dyspnoea, insomnia, appetite loss, constipation, diarrhoea, and financial difficulties in patients with MDD than in non-depressed patients. Patients with cancer typically have higher mean scores in the symptom scale and experience fatigue followed by pain and insomnia; common symptoms included fatigue (55\%), reduced role functioning (49\%), insomnia (46\%), pain (37\%), and dyspnoea (36\%), with vomiting being considered distressing.$^{28}$ Constipation is reported as a predictor for depression among patients with incurable cancer. ${ }^{29}$ Symptoms such as appetite loss and nausea and vomiting are prevalent among patients with cancer; appetite loss may be caused by active treatment regimens. ${ }^{24}$

In the present study, quality of life was poor in patients with MDD. This result is similar to that of Pamuk et $\mathrm{al}^{25}$ who reported a negative effect of depression on the global quality of life and physical, psychological, and social functioning among patients with depression and malignant cancer undergoing active treatment. Intracranial tumours and brain disorders are life-threatening and affect quality of life. Better understanding of the role of quality of life 
Table 1. Socio-demographic and clinical characteristics of participants $(n=100)$

\begin{tabular}{|c|c|}
\hline Characteristics & $\begin{array}{l}\text { No. }(\%) \text { of } \\
\text { participants }\end{array}$ \\
\hline \multicolumn{2}{|l|}{ Age (years) } \\
\hline $18-20$ & $2(2.0)$ \\
\hline $21-30$ & $15(15.0)$ \\
\hline $31-40$ & $21(21.0)$ \\
\hline $41-50$ & $25(25.0)$ \\
\hline $51-60$ & $21(21.0)$ \\
\hline $61-70$ & $15(15.0)$ \\
\hline 71 & $1(1.0)$ \\
\hline \multicolumn{2}{|l|}{ Sex } \\
\hline Women & $66(66.0)$ \\
\hline Men & $34(34.0)$ \\
\hline \multicolumn{2}{|l|}{ Ethnicity } \\
\hline Malay & $78(78.0)$ \\
\hline Chinese & $12(12.0)$ \\
\hline Indian & $9(9.0)$ \\
\hline Others & $1(1.0)$ \\
\hline \multicolumn{2}{|l|}{ Religion } \\
\hline Muslim & $78(78.0)$ \\
\hline Buddhist & $11(11.0)$ \\
\hline Hindu & $7(7.0)$ \\
\hline Christian & $3(3.0)$ \\
\hline Others & $1(1.0)$ \\
\hline \multicolumn{2}{|l|}{ Marital status } \\
\hline Single & $24(24.0)$ \\
\hline Married & $74(74.0)$ \\
\hline Widowed & $1(1.0)$ \\
\hline Divorced & $1(1.0)$ \\
\hline \multicolumn{2}{|l|}{ Children } \\
\hline Yes & $68(68.0)$ \\
\hline No & $32(32.0)$ \\
\hline \multicolumn{2}{|l|}{ Highest level of formal education } \\
\hline Primary & $13(13.0)$ \\
\hline Secondary & $48(48.0)$ \\
\hline College/university & $38(38.0)$ \\
\hline No education & $1(1.0)$ \\
\hline \multicolumn{2}{|l|}{ Highest certificate } \\
\hline $\begin{array}{l}\text { Primary School Evaluation Test } \\
\text { (UPSR/PSET) }\end{array}$ & $12(12.0)$ \\
\hline $\begin{array}{l}\text { Lower Certificate of Education } \\
(\mathrm{PMR} / \mathrm{SRP} / \mathrm{LCE})\end{array}$ & $14(14.0)$ \\
\hline $\begin{array}{l}\text { Malaysian Certificate of Education } \\
(\mathrm{SPM} / \mathrm{SPMV} / \mathrm{MCE})\end{array}$ & $29(29.0)$ \\
\hline $\begin{array}{l}\text { Malaysian Higher School Certificate } \\
\text { (STPM/HSC) }\end{array}$ & $3(3.0)$ \\
\hline Certificate/diploma & $20(20.0)$ \\
\hline Degree & $18(18.0)$ \\
\hline Master & $3(3.0)$ \\
\hline No education & $1(1.0)$ \\
\hline
\end{tabular}

Table 1. (cont'd)

\begin{tabular}{|c|c|}
\hline Characteristics & $\begin{array}{c}\text { No. }(\%) \text { of } \\
\text { participants }\end{array}$ \\
\hline $\begin{array}{l}\text { Occupation status } \\
\text { Working } \\
\text { Not working } \\
\text { Working sector } \\
\text { Government } \\
\text { Non-government } \\
\text { Self employment } \\
\text { Semi-government } \\
\text { Not working }\end{array}$ & $\begin{array}{r}21(21.0) \\
31(31.0) \\
1(1.0) \\
2(2.0) \\
45(45.0)\end{array}$ \\
\hline $\begin{array}{l}\text { Total monthly household income (RM) } \\
\text { 0-3000 } \\
3001-6000 \\
6001-9000 \\
>9001 \\
\text { Others }\end{array}$ & $\begin{array}{c}53(53.0) \\
13(13.0) \\
8(8.0) \\
4(4.0) \\
22(22.0)\end{array}$ \\
\hline $\begin{array}{l}\text { Year of diagnosis } \\
2015-2016 \\
2013-2014 \\
2011-2012 \\
2009-2010 \\
2007-2008 \\
2005-2006 \\
<2005 \\
\text { Others }\end{array}$ & $\begin{array}{c}34(34.0) \\
17(17.0) \\
11(11.0) \\
6(6.0) \\
7(7.0) \\
3(3.0) \\
14(14.0) \\
8(8.0)\end{array}$ \\
\hline $\begin{array}{l}\text { Neurological disorder } \\
\text { Astrocytic glioma } \\
\text { Meningioma } \\
\text { Pituitary adenoma } \\
\text { Carvenoma } \\
\text { Schwanoma } \\
\text { Craniopharyngioma } \\
\text { Ethmoid } \\
\text { Frontal lobe tumour } \\
\text { Fibrosarcoma } \\
\text { Cerebellar oedema } \\
\text { Germinoma } \\
\text { Haemorrhagic brain } \\
\text { Metastatic carcinoma } \\
\text { Brain lesion } \\
\text { Mucopyocele } \\
\text { Aneurysm } \\
\text { Hydrocephalus } \\
\text { Unclassified neurological disorder }\end{array}$ & $\begin{array}{c}13(13.0) \\
19(19.0) \\
15(15.0) \\
7(7.0) \\
5(5.0) \\
3(3.0) \\
1(1.0) \\
1(1.0) \\
1(1.0) \\
4(4.0) \\
1(1.0) \\
3(3.0) \\
1(1.0) \\
2(2.0) \\
1(1.0) \\
1(1.0) \\
3(3.0) \\
19(19.0)\end{array}$ \\
\hline $\begin{array}{l}\text { Treatment } \\
\text { Medication } \\
\text { Chemotherapy } \\
\text { Radiotherapy } \\
\text { Chemotherapy and radiotherapy } \\
\text { Medication and radiotherapy } \\
\text { Medication and waiting for surgery } \\
\text { Endoscopic operation radiotherapy } \\
\text { Surgery } \\
\text { Surgery and medication } \\
\text { Surgery, medication, and radiotherapy } \\
\text { Waiting for surgery } \\
\text { Waiting for chemotherapy } \\
\text { Waiting for laser treatment } \\
\text { Others }\end{array}$ & $\begin{aligned} 18 & (18.0) \\
4 & (4.0) \\
3 & (3.0) \\
1 & (1.0) \\
2 & (2.0) \\
1 & (1.0) \\
1 & (1.0) \\
30 & (30.0) \\
5 & (5.0) \\
1 & (1.0) \\
1 & (1.0) \\
1 & (1.0) \\
1 & (1.0) \\
31 & (31.0)\end{aligned}$ \\
\hline
\end{tabular}


Table 2. European Organisation for Research and Treatment of Cancer Quality of Life questionnaire version 3.0 scores (EORTC QLQ-C30) in patients with neurological disorder with or without depression (n=100)

\begin{tabular}{|lcccr|}
\hline \multirow{2}{*}{ EORTC QLQ-C30 } & \multicolumn{2}{c}{ Score, median (interquartile range) } & $\begin{array}{c}\text { Z statistic (Mann- } \\
\text { Whitney } \boldsymbol{U} \text { test) }\end{array}$ & p Value \\
\cline { 2 - 3 } Global health status & With depression & Non-depressed & & \\
\hline Functioning & $50.0(33.3)$ & $66.7(33.3)$ & -2.964 & 0.003 \\
$\quad$ Physical functioning & $63.3(41.7)$ & $86.7(26.7)$ & -2.951 & 0.003 \\
Role functioning & $66.7(50.0)$ & $83.3(33.3)$ & -2.308 & 0.021 \\
Emotional functioning & $50.0(41.7)$ & $75.0(27.1)$ & -4.272 & $<0.001$ \\
Cognitive functioning & $50.0(37.5)$ & $66.7(50.0)$ & -2.902 & 0.004 \\
Social functioning & $83.3(50.0)$ & $100.0(16.7)$ & -2.721 & 0.007 \\
\hline Symptom & & & & \\
Fatigue & $66.7(69.4)$ & $33.3(36.1)$ & -2.846 & 0.004 \\
Nausea and vomiting & $0.0(37.5)$ & $0.0(16.7)$ & -0.642 & 0.521 \\
Pain & $50.0(54.2)$ & $16.7(37.5)$ & -4.224 & $<0.001$ \\
Dyspnoea & $0.0(33.3)$ & $0.0(0.0)$ & -2.130 & 0.033 \\
Insomnia & $66.7(100.0)$ & $0.0(33.3)$ & -3.734 & $<0.001$ \\
Appetite loss & $0.0(66.7)$ & $0.0(0.0)$ & -3.073 & 0.002 \\
Constipation & $0.0(33.3)$ & $0.0(0.0)$ & -2.114 & 0.034 \\
Diarrhoea & $0.0(8.3)$ & $0.0(0.0)$ & -2.304 & 0.021 \\
\hline Financial difficulties & $33.3(100.0)$ & $0.0(33.3)$ & -2.064 & 0.039 \\
\hline
\end{tabular}

among patients with depression would help clinicians, health psychologists, psychiatrists, and counsellors to improve the overall treatment of patients.

There are limitations to the present study. Investigating depression and quality of life among neurological disorder patients is challenging because they have difficulties in responding actively during interviews owing to physical weakness and the severity of their illness. Thus, results should be interpreted with caution; the responses may have been influenced by the physical and emotional state of the participants at the time of the interviews.

\section{Conclusion}

Patients with MDD have reduced quality of life, especially in global health statuses, physical, role, emotional, cognitive, and social functioning, compared with non-depressed patients. Fatigue, pain, dyspnoea, insomnia, appetite loss, constipation, diarrhoea, and financial difficulties are prevalent among patients with MDD.

\section{Acknowledgement}

The authors would like to thank the staff of the Department of Neuroscience and the patients who enrolled in the study.

\section{Funding}

This study was funded in part by a short-term grant from University Sains Malaysia (304/PPSP/6315007) and the MyBrain15-MyPhd scholarship awarded to Priscilla Das.

\section{References}

1. Lim G, Rampal R, Halimah Y. Cancer Incidence in Peninsular Malaysia, 2003-2005. National Cancer Registry, Kuala Lumpur; 2008.

2. Guo Y, Musselman DL, Manatunga AK, Gilles N, Lawson KC, Porter MR, et al. The diagnosis of major depression in patients with cancer: a comparative approach. Psychosomatics 2006;47:376-84. Crossref

3. Thaker PH, Han LY, Kamat AA, Arevalo JM, Takahashi R, Lu C, et al. Chronic stress promotes tumor growth and angiogenesis in a mouse model of ovarian carcinoma. Nat Med 2006;12:939-44. Crossref

4. Cotter D, Mackay D, Chana G, Beasley C, Landau S, Everall IP. Reduced neuronal size and glial cell density in area 9 of the dorsolateral prefrontal cortex in subjects with major depressive disorder. Cereb Cortex 2002;12:386-94. Crossref

5. Rajkowska G, Miguel-Hidalgo JJ. Gliogenesis and glial pathology in depression. CNS Neurol Disord Drug Targets 2007;6:219-33. Crossref

6. Brain cells and depression/bipolar disorder. Available from: https:// www.dnalc.org/view/2087-Brain-cells-and-depression-bipolardisorder.html. Accessed 31 December 2018.

7. Passik SD, Dugan W, McDonald MV, Rosenfeld B, Theobald DE, Edgerton S. Oncologist's recognition of depression in their patients with cancer. J Clin Oncol 1998;16:1594-600. Crossref

8. Heimans JJ, Taphoorn MJ. Impact of brain tumour treatment on quality of life. J Neurol 2002;249:955-60. Crossref

9. Prieto JM, Atala J, Blanch J, Carreras E, Rovira M, Cirera E, et al. Role of depression as a predictor of mortality among cancer patients after stem-cell transplantation. J Clin Oncol 2005;23:6063-71. Crossref

10. Prieto JM, Atala J, Blanch J, Carreras E, Rovira M, Cirera E, et al. Patient-rated emotional and physical functioning among hematologic cancer patients during hospitalization for stem-cell transplantation. Bone Marrow Transplant 2005;35:307-14. Crossref

11. Daniel W. Biostatistics: A Foundation for Analysis in the Health 
Sciences. 7 ed. New York: John Wiley \& Sons; 1999.

12. Mainio A, Hakko H, Timonen M, Niemelä A, Koivukangas J, Räsänen P. Depression in relation to survival among neurosurgical patients with a primary brain tumor: a 5-year follow-up study. Neurosurgery 2005;56:1234-42. Crossref

13. Aaronson NK, Ahmedzai S, Bergman B, Bullinger M, Cull A, Duez NJ, et al. The European Organization for Research and Treatment of Cancer QLQ-C30: a quality-of-life instrument for use in international clinical trials in oncology. J Natl Cancer Inst 1993;85:365-76. Crossref

14. Sheehan D, Janavs J, Harnett-Sheehan K, Sheehan M, Gray C, Leucrubier Y, et al. M.I.N.I Mini International Neuropsychiatric Interview Version 6.0.0 DSM-IV. 2009. Crossref

15. Mukhtar F, Abu Bakar AK, Junus MM, Awaludin A, Abdul Aziz S, Midin M, et al. A preliminary study on the specificity and sensitivity values and inter-rater reliability of Mini International Neuropsychiatric Interview (MINI) in Malaysia. ASEAN J Psychiatry 2012;13:157-64.

16. Fayers P, Aaronson NK, Bjordal K, M Groenvold, D Curran, A Bottomley. EORTC QLQ-C30 Scoring Manual. 3rd Ed. Brussels: European Organisation for Research and Treatment of Cancer; 2001.

17. Wellisch DK, Kaleita TA, Freeman D, Cloughesy T, Goldman J. Predicting major depression in brain tumor patients. Psychooncology 2002;11:230-8. Crossref

18. Huang J, Zeng C, Xiao J, Zhao D, Tang H, Wu H, et al. Association between depression and brain tumor: a systematic review and metaanalysis. Oncotarget 2017;8:94932-43. Crossref

19. Mainio A, Hakko H, Niemelä A, Koivukangas J, Räsänen P. Depression in relation to anxiety, obsessionality and phobia among neurosurgical patients with a primary brain tumor: a 1-year follow-up study. Clin Neurol Neurosurg 2011;113:649-53. Crossref

20. Chen ML, Chang HK, Yeh CH. Anxiety and depression in Taiwanese cancer patients with and without pain. J Adv Nurs 2000;32:944-

\section{Crossref}

21. Okamura H, Watanabe T, Narabayashi M, Katsumata N, Ando M, Adachi I, et al. Psychological distress following first recurrence of disease in patients with breast cancer: prevalence and risk factors. Breast Cancer Res Treat 2000;61:131-7. Crossref

22. Massie MJ. Prevalence of depression in patients with cancer. J Natl Cancer Inst Monogr 2004;32:57-71. Crossref

23. Sharpley CF, Bitsika V, Christie DR. Understanding the causes of depression among prostate cancer patients: development of the Effects of Prostate Cancer on Lifestyle Questionnaire. Psychooncology 2009; 18:162-8. Crossref

24. Johnsen AT, Tholstrup D, Petersen MA, Pedersen L, Groenvold M. Health related quality of life in a nationally representative sample of haematological patients. Eur J Haematol 2009;83:139-48. Crossref

25. Pamuk GE, Harmandar F, Ermantaş N, Harmandar O, Turgut B, Demir M, et al. EORTC QLQ-C30 assessment in Turkish patients with hematological malignancies: association with anxiety and depression. Ann Hematol 2008;87:305-10. Crossref

26. Wellisch DK, Kaleita TA, Freeman D, Cloughesy T, Goldman J. Predicting major depression in brain tumor patients. Psychooncology 2002;11:230-8. Crossref

27. Spiegel D, Giese-Davis J. Depression and cancer: mechanisms and disease progression. Biol Psychiatry 2003;54:269-82. Crossref

28. Larsen J, Nordström G, Björkstrand B, Ljungman P, Gardulf A. Symptom distress, functional status and health-related quality of life before high-dose chemotherapy with stem-cell transplantation. Eur J Cancer Care (Engl) 2003;12:71-80. Crossref

29. Mystakidou K, Tsilika E, Parpa E, Katsouda E, Galanos A, Vlahos L. Assessment of anxiety and depression in advanced cancer patients and their relationship with quality of life. Qual Life Res 2005;14:182533. Crossref 